\begin{tabular}{|l|l|l|l|l|l|}
\hline J. Tek. Ling & Vol.11 & No.2 & Hal. $301-311$ & Jakarta, Mei 2010 & ISSN 1441-318X \\
\hline
\end{tabular}

\title{
PEMANFAATAN DIMETHYL ETHER (DME) SEBAGAI SUBSTITUSI BAHAN BAKAR MINYAK DAN LPG
}

\author{
Mohamad Sidik Boedoyo \\ Peneliti di Pusat Teknologi Pengembangan Sumberdaya Energi \\ Badan Pengkajian dan Penerapan Teknologi
}

\begin{abstract}
As a developing country, currently the energy demand in Indonesia increases rapidly. Although Indonesia has a huge of oil reserves the production of oil fuels as the main energy consumption has not been enough and should be imported. It is devised to substitute oil fuel with other resources such as liquefied coal, natural gas, biofuels and dimethyl ether (DME). In the short future, the use of DME as an alternative fuel appears to be a promising approach for reducing the uses of diesel oil and LPG. It can be described in to two approaches. First, due to the high cetane number of DME, it can be used for compression ignition engines which have higher thermal efficiencies compared to spark ignition engines. Second, due to the physical properties of DME, it can substitute oil fuels and LPG uses in industries, commercials, and households for lighting and cooking. Hence, DME production is not limited to one feedstock. DME can be derived from fossil fuel feedstocks, including natural gas and coal, as well as from renewable feedstock sources such as biomass. Since Indonesia have abundant of energy sources as DME raw material, such as natural gas, coal and biomass, utilization of DME into Indonesia energy system is necessary to be developed.
\end{abstract}

Key words :Energy Potential, Dimethyl Ether, Diesel Oil and LPG Substitution

\section{PENDAHULUAN}

\subsection{Latar Belakang}

Penggunaan bahan bakar minyak di Indonesia telah melewati puncak keseimbangan antara produksi dan konsumsi, sehingga saat ini Indonesia telah berubah dari negara pengeksporr minyak menjadi pengimport minyak.

Untuk mencukupi kebutuhan energi yang terus meningkat, pemanfaatan energi alternatif seperti batubara, gas bumi serta energi terbarukan terus dikembangkan, baik untuk pembangkitan tenaga listrik maupun sebagai bahan bakar substitusi bahan bakar minyak. Di sektor transportasi substitusi penggunaan bahan bakar minyak sulit untuk dilakukan karena adanya persyaratan fisik antara lain, mudah dibawa dan mempunyai padat energi yang tinggi. Beberapa upaya yang telah dilaksanakan antara lain ialah pengembangan Bahan Bakar Nabati baik berupa biodiesel, maupun bioethanol yang dapat menggantikan penggunaan minyak solar dan premium. Di sektor rumah tangga konversi minyak tanah ke LPG telah berhasil mengurangi penggunaan minyak tanah yang berarti mengurangi subsidi, tetapi konsumsi LPG meningkat tajam sehingga diperlukan ekspor LPG yang makin lama makin besar.

Pada kenyataannya pengembangan biodiesel dan bio ethanol sulit dilaksanakan karena terkendala oleh penyediaan lahan, 
harga yang berfluktuasi dan adanya persaingan antara penggunaan sebagai bahan bakar atau bahan pangan. Hal ini mendorong dilaksanakannya kajian dan penelitian tentang sumber energi alternatif lain sebagai substitusi bahan bakar minyak, seperti pencairan batubara, gasifikasi batubara maupun biomasa dan dimethyl ether (DME).

DME merupakan senyawa ether sederhana yang dapat diproduksi dari berbagai sumber bahan baku seperti gas bumi, batubara, serta biomasa, dan mempunyai angka cetan yang tinggi, dan sifat yang mendekati LPG seperti viskositas, titik didik dan tekanan, sehingga sangat penting untuk dikaji kemungkinan pemanfaatan DME untuk menggantikan atau mengurangi penggunaan minyak solar maupun LPG di Indonesia. DME selain dapat dimanfaatkan di Industri dan transportasi serta pembangkit listrik sebagai substitusi minyak solar, juga berpeluang untuk menggantikan LPG sebagai bahan bakar di sektor rumah tangga, komersial dan industri, yang saat ini sebagian besar diimpor. ${ }^{8)}$

\subsection{Tujuan}

Dalam makalah ini dilaksanakan kajian terhadap kemungkinan pemanfaatan Dimethyl Ether (DME) sebagai substitusi bahan bakar minyak dan LPG di Indonesia, berdasarkan potensi substitusi DME ke solar dan LPG,.
Disamping itu dalam rangka penyediaan energi nasional, diharapkan wilayah diluar pulau Jawa akan dapat menyediakan bahan baku untuk pembuatan DME seperti gas bumi, batubara maupun dari sumber energi biomasa termasuk sampah.

Diharapkan hasil kajian ini dapat digunakan sebagai acuan dalam perencanaan penyediaan energi nasional, khususnya dalam mencari solusi substitusi BBM dan LPG serta meningkatkan ketahanan dan keandalan energi nasional.

\section{METODOLOGI}

Metodologi kajian yang dilaksanakan meliputi tiga bagian yaitu pertama, melakukan analisis terhadap penyediaan energi nasional, mendalami masalah serta mencari alternatif solusi, kedua, melakukan analisis terhadap DME untuk melihat peluang pemanfaan DME sebagai substitusi bahan bakar minyak dan LPG, melakukan kajian terhadap proses pembuatan DME dan potensi penyediaan bahan baku DME, ketiga analisis kebutuhan dan produksi DME sebagai substitusi bahan bakar minyak dan bagian terakhir ialah analisis kesimpulan rekomendasi program pengembangan DME sebagai substitusi bahan bakar minyak. Secara umum metodologi kajian pengembangan DME sebagai substitusi bahan bakar minyak dapat dilihat pada gambar 1 .

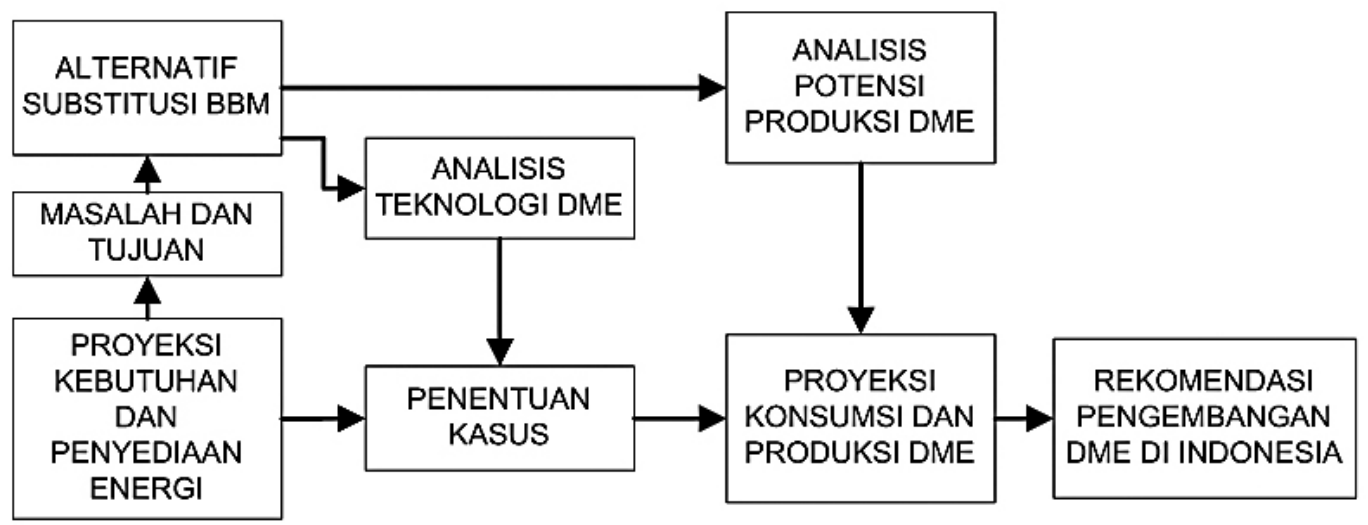

Gambar 1. Pengembangan DMEsebagai Substitusi BBM di Indonesia 


\subsection{Proyeksi Kebutuhan dan Penyediaan Energi}

Proyeksi kebutuhan dan penyadiaan energi yang merupakan basis dalam analisis pengembangan energi alternatif dengan berdasarkan potensi energi yang tersedia, dan kondisi penggunaan energi di masa depan. Proyeksi kebutuhan dan penyediaan energi diambil dari studi Outlook Energi 2009, PTPSE-BPPT yang dipublikasi awal tahun 2010. Dalam kajian ini diambil kasus dasar yaitu pertumbuhan ekonomi $4 \%$ per tahun dan harga minyak $\$ 30$ untuk seluruh perioda kajian $(2010-2030) .{ }^{1)}$

Selain dari proyeksi kebutuhan dan penyediaan energi, juga dibahas potensi sumberdaya energi yang dimiliki Indonesia dan perkiraan lama pemanfaatan potensi energi tersebut yang bertujuan untuk menggali kemungkinan pemanfaatan potensi sumberdaya energi tersebut lebih lanjut, peningkatan ekspor maupun impor di masa depan.

\subsection{Pemanfaatan dan Produksi DME}

Analisis terhadap pemanfaatan DME meliputi gambaran tentang DME, cara pembuatan serta sumberdaya yang dapat dimanfaatakan sebagai bahan baku pembuatan DME. Kajian terhadap kebutuhan energi, potensi sumberdaya energi yang ada menghasilkan dua buah kasus pemanfaatan DME di Indonesia sebagai substitusi minyak solar dan LPG. Kasus I merupakan kondisi yang paling memungkinkan untuk dicapai dalam pemanfaatan DME, sedangkan kasus II merupakan kondisi yang paling optimal dalam penerapan DME pada sistem energi di Indonesia, dilihat dari sisi ketahanan energi.

\subsection{Kajian Pemanfaatan DME di Indonesia}

Penerapan Kasus I dan Kasus II pada sistem energi di Indonesia akan menunjukkan volume substitusi minyak solar dan LPG dengan DME serta perhitungan pemanfaatan gas, batubara dan biomasa sebagai bahanb baku pembuatan DME.

\section{GAMBARAN UMUM DME}

DME merupakan merupakan senyawa ether yang paling sederhana, berbentuk gas yang tidak berwarna dengan bau ether dan larut dalam air maupun dalam minyak, tidak bersifat karsinogenik, teratogenik, mutagenik dan tidak beracun.4) DME mempunyai formula $\mathrm{CH}_{3}-\mathrm{O}-\mathrm{CH}_{3}$ atau rumus empiris $\mathrm{C}_{2} \mathrm{H}_{6} \mathrm{O}$.

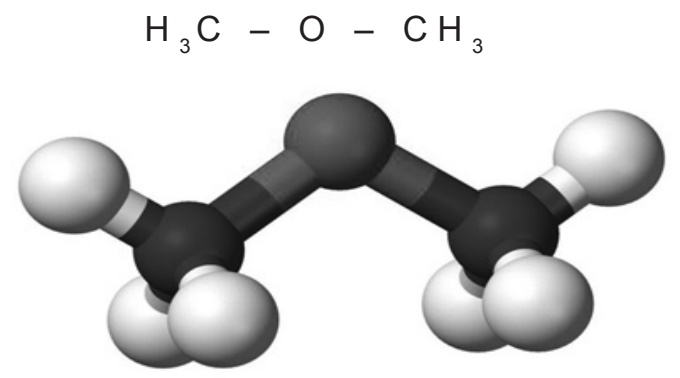

Pemanfaatan DME akan menghasilkan dampak lingkungan rendah, dimana pembakarannya tidak menghasilkan asam belerang (SOx) dan asap, serta menghasilkan $\mathrm{NOx}$ dan $\mathrm{CO}$ yang sangat rendah. DME

Mengingat DME tidak beracun, mudah dicairkan dan mudah dalam penanganan, maka bahan ini dapat dimanfaatakan sebagai bahan bakar sektor rumah tangga dan industri (substitusi LPG dan minyak tanah), bahan bakar transportasi (kendaraan diesel, fuel cell), bahan bakar pembangkit listrik (pembangkit thermal kogenerasi dan fuel cell), bahan baku untuk produk kimia, dan sebagai pelarut.

Secara umum DME dapat digunakan sebagai:

- Materi pendingin (refregerant)

- Sebuah pendorong (propellant) untuk produk aerosol

- Bahan pelarut

- Sebuah agen ekstraksi 
- Media reaksi kimia

- Sebuah bahan untuk pengelasan, pemotongan dan pematrian, Bahan bakar dengan multi-tujuan.

\subsection{Pemanfaatan DME Sebagai Substitusi BBM dan LPG}

DME dapat digunakan sebagai bahan bakar alternative substitusi LPG, LNG, minyak solar dan bensin dengan pembakaran bersih, dengan menggunakan mesin diesel, mesin bensin (30\% DME / 70\% LPG). dan turbin gas. DME bekerja sangat baik sebagai substitusi dan campuran dalam mesin diesel karena mempunyai angka cetane, yang lebih besar dari 65 - 70 jika dibandingkan dengan minyak diesel yang hanya $40-56$. ${ }^{[6]}$ Saat ini Uni Eropa sedang mempertimbangkan potensi DME dalam campuran biofuel di tahun 2030. ${ }^{(2)}$

DME sebagai bahan bakar bersifat kurang melumasi, oleh karena itu penggunaan DME secara penuh $(100 \%)$ harus ditambah aditif untuk meningkatkan fungsi pelumasannya, antara lain dengan biodiesel atau minyak nabati sejumlah $5 \%$ $-10 \%$.

Mengingat DME mempunyai viskositas yang rendah dibanding minyak solar serta sifat yang kurang melumasi untuk melindungi permukaan sistem injeksi bahan bakar, maka salah satu strategi ialah mencampur DME dengan minyak solar untuk mendapatkan pembakaran yang bersih dan tetap memperoleh karakteristik bahan bakar yang memuaskan, tanpa perlu merubah disain dari pompa dan injektor bahan bakar.

DME dengan minyak solar akan tercampur secara merata dan cepat pada berbagai pangsa campuran. ${ }^{9)}$ Perlu diteliti bahan aditif yang khusus dibuat untuk pemanfaatan DME agar dapat meningkatkan viskositas mendekati minyak solar, dimana lapisan yang melapisi permukaan logam akan dapat menghilangkan sifat negatif pelumasan DME.
DME sangat mungkin untuk dimanfaatkan sebagai substitusi LPG, mengingat sifat-sifat dasarnya yang tidak terlalu berbeda. Pemanfaatan DME sebagai substitusi LPG diperkirakan tidak akan merubah spesifikasi teknik tabung LPG, selain menggantikan karet penyekat (seal) dengan bahan yang cocok terhadap DME. Campuran 20\% DME pada LPG tidak memerlukan perubahan apapun pada tabung dan perlengkapan LPG lainnya.

\subsection{Proses Produksi DME}

Secara tradisional, DME diproduksi melalui dua tahap proses yaitu sintesis metanol (bisa diperoleh dari konversi biomass atau reaksi gas karbon monoksida atau karbon dioksida dengan hidrogen) kemudian proses penarikan molekul air (dehidrasi) terhadap molekul metanol yang terbentuk sehingga menghasilkan satu molekul DME dan molekul air. ${ }^{4)}$ reaksi ini bersifat reversibel. Dehidrasi ini memerlukan katalis logam atau semi-logam oksida misalnya aluminium oksida (gamma- $\mathrm{Al}_{2} \mathrm{O}_{3}$ ) pada suhu diatas $100{ }^{\circ} \mathrm{C}$ dan tekanan beberapa atmosfer.

Reaksi diatas dapat ditunjukkan dalam persamaan berikut:

methanol $\rightarrow$ dimethyl ether + water

metanol $\rightarrow$ dimetil eter + air

$2 \mathrm{CH}_{3} \mathrm{OH} \rightarrow \mathrm{CH}_{3} \mathrm{OCH}_{3}+\mathrm{H}_{2} \mathrm{O}_{2} \mathrm{Ch}_{3}$ $\mathrm{OH} \rightarrow \mathrm{CH}_{3} \mathrm{OCH}_{3}+\mathrm{H}_{2} \mathrm{O}$

Saat ini proses sintesis DME dua tahap tersebut mulai ditinggalkan dan penelitian yang diarahkan untuk memproduksi DME melalui proses satu tahap mengalami peningkatan pesat. Sintesis DME satu tahap adalah dengan cara mereaksikan gas karbon monoksida dan atau karbon dioksida dengan gas hidrogen menggunakan katalis kombinasi (kombo) pada tekanan diatas 30 atmosfer dan suhu diatas $150{ }^{\circ} \mathrm{C}$. Jika kita lihat proses pembuatan metanol yang juga menggunakan bahan baku serupa 
maka sebenarnya sintesis DME satu tahap hanyalah kepanjangan dari proses pembuatan metanol. Faktor utama yang mempengaruhi ketinggian tingkat produksi (yield) proses produksi DME satu tahap adalah efisiensi dan efektifitas katalis yang digunakan untuk sintesis metanol yang umumnya dikenal sebagai katalis kombo, yaitu katalis (terdiri dari tembaga-sengalumina) dan katalis untuk proses dehidrasi metanol (gamma-alumina).

Gas karbon monoksida dan hidrogen (disebut syn-gas) sebagai bahan baku DME maupun metanol dapat diperoleh dari gas bumi, serta gasifikasi batubara dan biomasa.

Penggunaan bahan padat seperti biomasa dan batubara akan melalui proses gasifikasi terlebih dahulu untuk menghasilkan syngas pada pembutan DME, dibanding penggunaan bahan gas seperti gas bumi maupun LPG. Untuk memperoleh efisiensi yang tinggi pada proses gasifikasi bahan padat, biomasa dan batubara harus melalui proses persiapan; seperti pemipilan (chipping) untuk biomassa atau produksi bubur (coal slurry) untuk batubara.

Gambar 2. menunjukkan aliran proses pembuatan DME dari berbagai bahan baku mulai dari bahan baku sampai ke DME.
Gambaran terhadap proses diatas menunjukkan bahwa Indonesia memiliki potensi untuk menjadi salah satu produsen terbesar DME karena cadangan gas alam termasuk methan yang diperoleh dari Coal Bed Methane (CBM) yang sangat besar, demukian juga batubara dan biomasa. Analisis terhadap ketersediaan bahan baku akan memberikan gambaran nyata kelayakan pemanfaatan DME sebagai substitusi bahan bakar minyak dan LPG.

\section{HASIL DAN PEMBAHASAN}

\subsection{Proyeksi Kebutuhan dan Penyediaan Energi}

Proyeksi kebutuhan dan penyediaan energi yang menjadi bahan kajian diambil dari Outlook Energi Indonesia 2009 yang dipublikasi oleh Pusat Teknologi Pengembangan Sumberdaya Energi, BPPT untuk kasus dasar yaitu harga minyak rendah (\$30 per barel) dan pertumbuhan ekonomi (PDB) rendah (4\% per tahun). ${ }^{1)}$

Proyeksi kebutuhan energi Indonesia dari tahun 2010 sampai 2030 terdiri dari BBM, batubara, gas, LPG, listrik dan biomasa, dimana BBM merupakan gabungan dari premium, solar, minyak bakar, dan

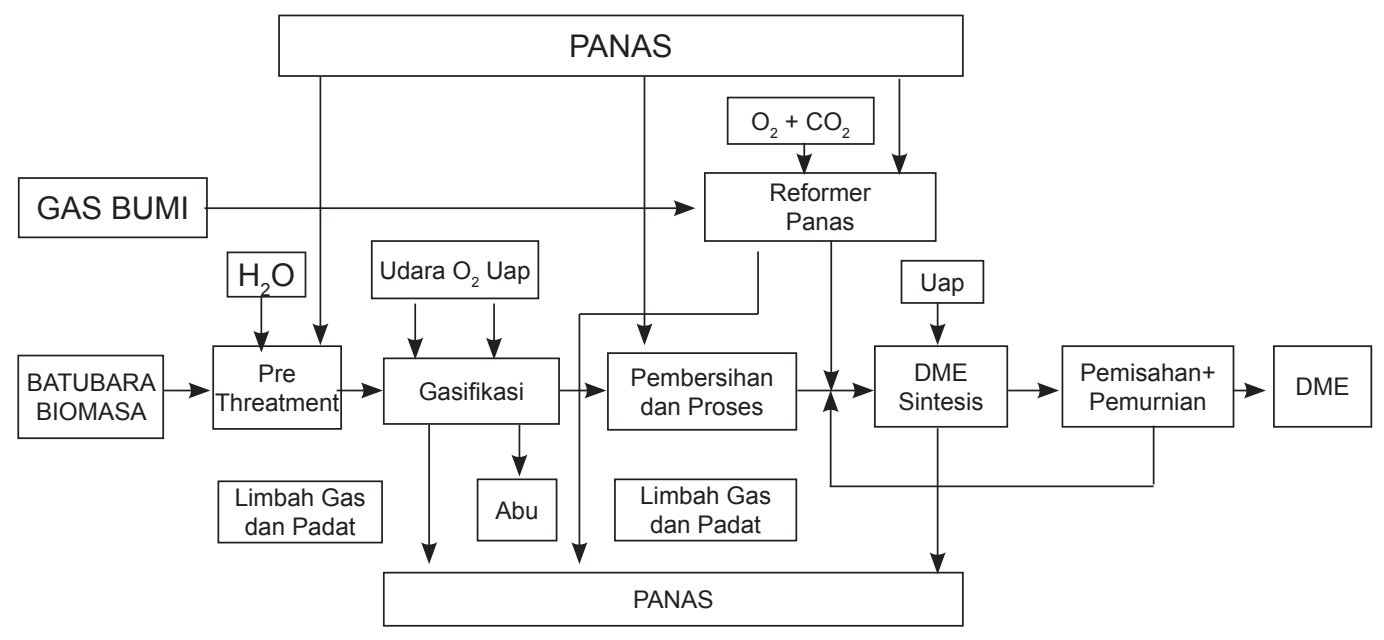

Gambar 2. Aliran Proses Pembuatan DME Berbagai Bahan baku 
minyak tanah. Semua jenis energi tersebut merupakan energi yang langsung dipakai untuk aktifitas dan tidak termasuk yang dipergunakan untuk pembangkitan listrik. Tabel 1 menunjukan proyeksi kebutuhan energi final di Indonesia dari tahun 2010 sampai 2030.

Tabel 1. Proyeksi Kebutuhan Energi Indonesia

(juta SBM)

\begin{tabular}{|l|l|l|l|l|l|}
\hline B Bakar & 2010 & 2015 & 2020 & 2025 & 2030 \\
\hline BBM & 339.33 & 381.65 & 447.25 & 510.86 & 706.56 \\
\hline Batubara & 104.45 & 108.82 & 147.03 & 190.52 & 239.87 \\
\hline Gas & 96.44 & 126.52 & 169.96 & 220.07 & 208.12 \\
\hline LPG & 44.46 & 68.60 & 81.52 & 99.20 & 114.22 \\
\hline Listrik & 86.85 & 109.43 & 154.16 & 225.57 & 329.88 \\
\hline Biofuel & 9.48 & 22.62 & 45.86 & 88.04 & 134.35 \\
\hline Biomasa & 213.14 & 175.72 & 140.83 & 111.33 & 86.84 \\
\hline
\end{tabular}

Sumber: Outlook Energi Indonesia ${ }^{3)}$

Dari tabel diatas terlihat bahwa walaupun biofuel sudah dikembangkan dengan laju pertumbuhan $14 \%$ per tahun tetapi peningkatan penggunaan BBM masih mencapai 3,7\% per tahun.

Disamping itu terlihat bahwa pemanfaatan potensi biomasa pada tahun 2010 sebesar 213 Juta SBM terus menurun dengan laju - 4,5\% per tahun sehingga mencapai 86,84 juta SBM pada tahun 2030 . Hal ini menunjukkan bahwa biomasa yang potensinya pada saat ini belum dimanfaatkan secara optimal, seperti limbah kelapa sawit, limbah pertanian dan limbah perkotaan akan dapat dikembangkan secara intensif.

Pemanfaatan biomasa sebagai energi menurun karena beralih ke energi komersial yang lebih mudah dan nyaman untuk digunakan.

Permasalahan utama dalam penyediaan energi nasional ialah sampai tahun 2030 kebutuhan BBM terus meningkat padahal cadangan minyak bumi Indonesia terus menurun, bahkan Indonesia sudah menjadi negara pengimpor minyak dan sejak September 2008 keluar dari keanggotaan OPEC. ${ }^{3)}$ Oleh karena itu perlu dikembangkan sumber energi alternatif yang dapat menggantikan penggunaan BBM.

Dari sumber energi di Indonesia ada empat alternatif yang dapat menjadi substitusi BBM yaitu bahan bakar nabati (BBN), pencairan batubara, gasifikasi batubara dan dimetil ether (DME). Sesuai dengan Outlook Energi Indonesia 2009, PTPSEBPPT, penggunaan bahan bakar nabati yang tumbuh sebesar $14 \%$ per tahun dari tahun 2010 - 2030 agak sulit untuk dikembangkan lebih lanjut karena kendala ketersediaan lahan dan persaingan antara produk makanan dan energi. Oleh karena itu mengingat potensi batubara yang tinggi di Indonesia, pencairan dan gasifikasi batubara merupakan alternatif yang potensial. Disamping kedua alternatif tersebut DME yang dapat diproduksi dari gas bumi, batubara dan biomasa perlu diperhatikan karena Indonesia memiliki potensi gas alam termasuk CBM yang besar dan hampir semua wilayah memiliki potensi biomasa, termasuk limbah pertanian, hutan dan sampah yang dapat dimanfaatkan sebagai bahan baku DME.

\subsection{Potensi Sumberdaya Energi sebagai bahan baku DME}

Dalam kaitan penyediaan DME maka perlu diperhitungkan potensi sumberdaya energi yang dapat menjadi bahan baku DME seperti gas bumi, batubara dan biomasa.

Potensi sektor ESDM yang mencakup sumber daya energi yang dikandung oleh bumi Indonesia antara lain: energi fosil dengan cadangan minyak bumi sebesar 8,2 miliar barel, gas bumi sebesar 170 TSCF, batubara sebesar 21 miliar ton; energi non fosil sumber daya panas bumi sebesra 28 GW, dan tenaga air sebesra 75 GW. Dari potensi tersebut, potensi yang berhubungan erat dengan pengembangan DME ialah potensi minyak bumi, batubara, gas bumi, CBM dan biomasa. Cadangan dan potensi pada tahun 2008 dapat dilihat pada Tabel 2.

Perhitungan potensi biomasa diambil berdasarkan analisis terhadap produknya 
biomasanya seperti limbah pertanian, limbah hutan (diluar limbah kelapa sawit dan sampah kota) dalam buku Studi Analisis dan Kajian Bidang Teknologi Energi, oleh koordinator bidang teknologi energi BPPT pada tahun 2003. Dengan anggapan bahwa secara rata-rata nilai kalor 1 kilogram limbah setara dengan 0,8 kg kayu, dan konversi energi untuk kayu dari ton ke SBM adalah 2,2978, maka dapat diperhitungkan potensi limbah pada tahun 2001 secara keseluruhan dalam setara barel minyak.
2007, dimana pada tahun 1994 diperkirakan sampah perkotaan di Indonesia mencapai 22,5 juta ton yang meningkat menjadi 53,7 juta ton pada tahun 2020.

Cadangan dan potensi energi seperti tercantum dalam Tabel 1 dan 2 menunjukkan bahwa energi alternatif masih memungkinkan untuk dikembangkan lebih lanjut, terutama biomasa dan sampah yang mempunyai potensi cukup besar dan akan mencemari lingkungan bila tidak dimanfaatkan dengan baik.

Tabel 2. Potensi dan Cadangan Sumberdaya Energi

\begin{tabular}{|l|l|l|l|l|}
\hline Sumber Energi & Sumberdaya & Cadangan & Produksi & $\begin{array}{l}\text { Cad/Prod } \\
\text { (Tahun })\end{array}$ \\
\hline Minyak Bumi & 56,60 miliar barel & 8,22 miliar barel & 357,51 juta barel & 23 \\
\hline Gas Bumi & 334,50 TSCF & 170,10 TSCF & 2,88 TSCF & 63 \\
\hline Batubara & 104,80 miliar ton & 18,78 miliar ton & 229,20 juta ton & 82 \\
\hline CBM & 453,00 TSCF & & \multicolumn{2}{l|}{} \\
\hline Biomasa & Potensi & Kapasitas terpasang \\
\hline
\end{tabular}

Sumber: Blueprint PEN 2010-2025 ESDM, 2009 5)

Untuk menghitung proyeksi sampai 2030, dari studi tersebut diambil pertumbuhan potensi biomasa sebesar $0,63 \%$ per tahun. Khusus untuk sampah, sebagai dasar perhitungan potensi data diambil dari makalah Perngelolaan dan Pemanfaatan Sampah Organik Menjadi Briket Arang dan Asap Cair, Nisandi, Seminar Nasional Teknologi 2007 (SNT 2007) Yogyakarta,

Tabel 3. Potensi Energi Limbah Biomasa ${ }^{7)}$

\begin{tabular}{|l|l|l|l|l|l|l|}
\hline \multirow{2}{*}{ No } & \multirow{2}{*}{$\begin{array}{c}\text { Jenis } \\
\text { Limbah }\end{array}$} & \multicolumn{5}{|c|}{ Potensi Limbah } \\
\cline { 3 - 7 } & & $\mathbf{2 0 1 0}$ & $\mathbf{2 0 1 5}$ & $\mathbf{2 0 2 0}$ & $\mathbf{2 0 2 5}$ & $\mathbf{2 0 3 0}$ \\
\hline 1 & Jerami & 103 & 107 & 110 & 114 & 117 \\
\hline 2 & Sekam & 30 & 32 & 32 & 33 & 34 \\
\hline 3 & Merang & 29 & 30 & 31 & 32 & 33 \\
\hline 4 & Jagung & 27 & 28 & 29 & 29 & 30 \\
\hline 5 & Ubi kayu & 20 & 20 & 21 & 21 & 22 \\
\hline 6 & $\begin{array}{l}\text { Kedelai\& } \\
\text { Kacang }\end{array}$ & 6 & 6 & 7 & 7 & 7 \\
\hline 7 & Kayu & 6 & 6 & 6 & 6 & 6 \\
\hline 8 & Kayu lain & 2 & 2 & 2 & 2 & 3 \\
\hline 9 & Sampah ${ }^{*}$ ) & 42 & 51 & 62 & 75 & 92 \\
\hline \multicolumn{7}{|l|}{ Total } \\
\hline
\end{tabular}

Analisis terhadap cadangan minyak bumi menunjukkan bahwa setelah tahun 2010 Indonesia tidak mampu melaksanakan ekspor minyak bumi dan seluruh produksi dimanfaatkan di dalam negeri ditambah impor minyak bumi. Kondisi ini juga berlaku pada pemanfaatan LPG sebagai substitusi minyak tanah di sektor rumah tangga dan komersial, dimana telah dikembangkan program Pemerintah dalam konversi Mitan ke LPG. Saat ini konsumsi LPG sudah jauh diatas kemampuan produksi LPG Indonesia dan akan terus meningkat di tahun-tahun mendatang. Tabel 4 menggambarkan tentang proyeksi produksi, konsumsi, impor dan ekspor minyak mentah dari tahun 2010 sampai tahun 2030 .

Tabel 4. Proyeksi Produksi, Konsumsi Ekspor, Impor Minyak Mentah

(Juta Barel)

\begin{tabular}{|l|l|l|l|l|l|}
\hline & 2010 & 2015 & 2020 & 2025 & 2030 \\
\hline Produksi & 353 & 299 & 203 & 129 & 129 \\
\hline Ekspor & -99 & -1 & 0 & 0 & 0 \\
\hline Impor & 86 & 83 & 369 & 548 & 663 \\
\hline Konsumsi & 340 & 380 & 572 & 677 & 793 \\
\hline
\end{tabular}


Tabel 5. Produksi, Konsumsi, Impor, Ekspor LPG

(Juta Ton)

\begin{tabular}{|l|l|l|l|l|l|}
\hline & 2010 & 2015 & 2020 & 2025 & 2030 \\
\hline Produksi & 0.8 & 0.9 & 1.3 & 1.5 & 1.8 \\
\hline Ekspor & -1.0 & -0.9 & -1.1 & 0.0 & 0.0 \\
\hline Impor & 5.5 & 8.7 & 10.1 & 10.9 & 12.4 \\
\hline Konsumsi & 5.6 & 8.8 & 10.4 & 12.2 & 14.2 \\
\hline
\end{tabular}

Agak sedikit berlainan ialah dalam gas bumi, dimana sampai tahun 2030 diperkirakan produksi gas bumi Indonesia masih mencukupi untuk memenuhi konsumsi domestik, tetapi komitmen untuk memenuhi kontrak ekspor LNG jangka panjang menyebabkan diperlukannya impor LNG, lihat Tabel 6 ..

Tabel 6. Proyeksi Produksi, Konsumsi, Impor dan Ekspor Gas dan LNG (TCF)

\begin{tabular}{|l|l|l|l|l|l|}
\hline & 2010 & 2015 & 2020 & 2025 & 2030 \\
\hline Produksi Gas & 3095 & 2911 & 2631 & 1752 & 1538 \\
\hline Ekspor Gas & 304 & 343 & 199 & 0 & 0 \\
\hline Konsumsi. Gas & 973 & 1563 & 1852 & 1473 & 1457 \\
\hline Ekspor LNG & 1496 & 838 & 786 & 569 & 404 \\
\hline Impor LNG & 0 & 0 & 305 & 330 & 354 \\
\hline
\end{tabular}

\subsection{Pemilihan Kasus Dalam Pemanfaatan DME Sebagai Alternatif Energi.}

Dalam rangka mengurangi kebutuhan akan bahan bakar minyak, maka dimetil ether (DME) yang mempunyai sifat mendekati LPG dapat dimanfaatkan sebagai substitusi pemakaian bahan bakar minyak maupun LPG.

Mengingat sifat dasar DME yang mempunyai angka cetan tinggi dan dekat dengan LPG, maka pemanfaatan DME yang terutama adalah untuk substitusi minyak solar untuk sektor transportasi, industri dan pembangkit listrik, serta substitusi LPG pada sektor industri dan perumahan.

Beberapa hal menjadi dasar bagi pemilihan maupun penentuan kasus untuk pemanfaata DME, antara lain ialah kondisi penyediaan energi, potensi yang tersedia, dan kemungkinan penyerapan DME oleh sektor terkait. Dengan batasan antara lain, potensi biomasa maksimum yang dapat dimanfaatkan sebagai DME adalah sekitar $40 \%$ potensi yang ada. Peningkatan konsumsi batubara yang dapat dipakai sebagai bahan baku DME secara umum tidak dibatasi mengingat pemanfaatan batubara domestik masih dalam kategori moderat, kemungkinan yang ada ialah membatasi ekspor batubara. Melihat konsumsi gas bumi yang terus meningkat, pemakaian gas bumi untuk produksi DME diperhitungkan hanya sampai tahun 2020. Dengan melihat kondidi diatas maka dalam pemanfaatan DME diusulkan dua target atau dua kasus yang sangat dipengaruhi oleh kemampuan penyediaan bahan baku DME yaitu batubara, gas bumi dan biomasa sebagai terlihat pada tabel 7. berikut

Kasus I adalah kondisi yang paling memungkinkan dalam produksi dan pemanfaatan DME dilihat dari penyediaan bahan bakunya serta investasi, sedangkan Kasus II adalah kondisi yang optimum bagi pengembangan DME sebagai alternatif substitusi BBM dan LPG di Indonesia. dilihat dari ketahanan energi nasional.

Tabel 7. Penurunan Pemakaian BBM dan LPG

\begin{tabular}{|l|l|l|l|l|l|l|}
\hline \multirow{2}{*}{ Kasus } & \multicolumn{5}{|c|}{ Target Penurunan (\%) } \\
\cline { 2 - 7 } & & 2010 & 2015 & 2020 & 2025 & 2030 \\
\hline \multirow{3}{*}{ I } & Solar & 0 & 5,0 & 7,5 & 10,0 & 15,0 \\
\cline { 2 - 7 } & LPG & 0 & 5,0 & 10,0 & 15,0 & 20,0 \\
\hline \multirow{3}{*}{ II } & Solar & 0 & 5,0 & 10 & 15,0 & 20,0 \\
\cline { 2 - 7 } & LPG & 0 & 5,0 & 15,0 & 25,0 & 40,0 \\
\hline
\end{tabular}

\subsection{Analisis Pemanfaatan DME sebagai substitusi BBM dan LPG}

Dari target penurunan pada Tabel 7 diperoleh gambaran tentang pengurangan konsumsi BBM pada Kasus 1 dan Kasus II terhadap Kasus Dasar (Tabel 1), serta peningkatan konsumsi LPG dan DME, seperti ditunjkukan pada Tabel 8.. Berdasarkan hasil perhitungan Konsumsi BBM, LPG dan DME pada Tabel 8. dapat dihitung pemanfaatan 
penyediaan bahan baku produksi DME yaitu gas bumi, biomasa dan batubara sesuai dengan kemampuan penyediaan ketiga sumber energi diatas.

Tabel 9. menunjukkan penetrasi setiap jenis sumber energi sebagai bahan baku pembuatan DME, yaitu gas bumi, batubara dan biomasa menurut pangsa penerapannya dalam \%, jumlah/unit energi serta dalam unit fisik.

\section{KESIMPULAN DAN REKOMENDASI}

\subsection{Kesimpulan}

Hal yang dapat disimpulkan dari kajian pemanfaatan DME sebagai substitusi BBM dan LPG adalah:

1. Kasus 1 menunjukkan bahwa pada tahun 2030 akan diperlukan biomasa sebanyak 53,4 Juta Ton dan batubara sejumlah 185 Juta Ton. Sedangkan untuk kasus 2 akan diperlukan biomasa sebanyak 83,2 Juta Ton dan batubara sejumlah 285 Juta Ton.

2. Pemanfaatan biomasa sejumlah tersebut masih memungkinkan dengan pertimbangan bahwa hanya $25 \%$ dari potensi biomasa yang akan dimanfaatkan sebagai bahan baku DME.

3. Sedangkan untuk batubara, bila dilihat dari potensinya yang masih sangat besar, adalah memungkinkan sebagai bahan baku DME.

4. Gas bumi yang pada awal periode masih dapat dimanfaatkan untuk mengganti sejumlah 5\% Solar dan 5\% LPG, pada periode 2020 sudah tidak memungkinkan untujk dipakai sebagai bahan baku DME karena digunakan

Tabel 8. Konsumsi BBM, LPG dan DME untuk Kasus Dasar, Kasus I dan Kasus II

(Juta SBM)

\begin{tabular}{|c|c|c|c|c|c|c|c|c|c|c|c|c|c|c|c|}
\hline \multirow{2}{*}{$\begin{array}{l}\text { Bahan } \\
\text { Bakar }\end{array}$} & \multicolumn{5}{|c|}{ Kasus Dasar } & \multicolumn{5}{|c|}{ Kasus I } & \multicolumn{5}{|c|}{ Kasus II } \\
\hline & 2010 & 2015 & 2020 & 2025 & 2030 & 2010 & 2015 & 2020 & 2025 & 2030 & 2010 & 2015 & 2020 & 2025 & 2030 \\
\hline BBM & 339 & 382 & 447 & 511 & 707 & 339 & 373 & 434 & 491 & 656 & 339 & 374 & 429 & 482 & 639.1 \\
\hline LPG & 45 & 69 & 99 & 82 & 114 & 45 & 65 & 73 & 84 & 91 & 44 & 65 & 69 & 74 & 68.5 \\
\hline DME & - & - & - & - & - & 0 & 12 & 22 & 35 & 73 & 0 & 12 & 30 & 54 & 113.1 \\
\hline
\end{tabular}

Tabel 9. Kebutuhan Gas bumi, Batubara dan Biomasa Untuk Penyediaan DME.

\begin{tabular}{|c|c|c|c|c|c|c|c|c|c|c|c|}
\hline \multirow{2}{*}{$\begin{array}{l}\text { Bahan } \\
\text { Baku }\end{array}$} & \multirow{2}{*}{ Unit } & \multicolumn{5}{|c|}{ KASUS I } & \multicolumn{5}{|c|}{ KASUS II } \\
\hline & & 2010 & 2015 & 2020 & 2025 & 2030 & 2010 & 2015 & 2020 & 2025 & 2030 \\
\hline Gas & \multirow{3}{*}{$\%$} & $0 \%$ & $40 \%$ & $20 \%$ & $0 \%$ & $0 \%$ & $0 \%$ & $40 \%$ & $20 \%$ & $0 \%$ & $0 \%$ \\
\hline Biomasa & & $0 \%$ & $20 \%$ & $30 \%$ & $40 \%$ & $40 \%$ & $0 \%$ & $20 \%$ & $30 \%$ & $40 \%$ & $40 \%$ \\
\hline Batubara & & $0 \%$ & $40 \%$ & $50 \%$ & $60 \%$ & $60 \%$ & $0 \%$ & $40 \%$ & $50 \%$ & $60 \%$ & $60 \%$ \\
\hline Gas & \multirow{3}{*}{$\begin{array}{l}\text { Juta } \\
\text { SBM }\end{array}$} & 0.00 & 4.62 & 4.34 & 0.00 & 0.00 & 0.00 & 4.62 & 6.06 & 0.00 & 0.00 \\
\hline Biomasa & & 0.00 & 2.31 & 6.51 & 13.80 & 29.37 & 0.00 & 2.31 & 9.08 & 21.69 & 45.25 \\
\hline Batubara & & 0.00 & 4.62 & 10.85 & 20.69 & 44.05 & 0.00 & 4.62 & 15.14 & 32.53 & 67.87 \\
\hline Gas & $\begin{array}{l}\text { Juta } \\
\text { SCF }\end{array}$ & 0.00 & 1.37 & 1.29 & 0.00 & 0.00 & 0.00 & 1.37 & 1.80 & 0.00 & 0.00 \\
\hline Biomasa & $\begin{array}{l}\text { Juta } \\
\text { Ton }\end{array}$ & 0.00 & 4.24 & 11.96 & 25.36 & 53.99 & 0.00 & 4.24 & 16.70 & 39.87 & 83.18 \\
\hline Batubara & $\begin{array}{l}\text { Juta } \\
\text { Ton }\end{array}$ & 0.00 & 19.39 & 45.55 & 86.91 & 185.02 & 0.00 & 19.39 & 63.59 & 136.63 & 285.06 \\
\hline
\end{tabular}


secara langsung di Industri, komersial, rumah tangga dan pembangkitan listrik. Kondisi tersebut akan berbeda bila potensi CBM telah terukur dengan benar dan dapat dimanfaatkan sebagai bahan baku DME.

5. PenggunaanDMEselainmenguntungkan secara ekonomi, meningkatkan ketahanan energi nasional dengan mengurangi impor BBM, merupakan bahan bakar yang ramah lingkungan karena menghasilkan emisi yang rendah, baik terhadap lingkungan lokal maupun lingkungan global.

\subsection{Rekomendasi}

Beberapa hal yang dapat direkomendasikan antara lain adalah

1. Agar DME berbahan baku batubara dapat diproduksi sesuai atau lebih dari target, maka sebaiknya ekspor batubara sejak tahun 2020 dihentikan. Pelaksanaan DMO (domestic market obligation) batubara yang mengurangi atau membatasi ekspor sulit untuk dikontrol dan menurunkan ketahanan energi nasional..

2. Program pengembangan DME harus melalui studi atau penelitian secara komprehensif, meliputi kajian tentang pemanfaatan DME, peraturan perundangannya, potensi produksi dari berbagai bahan baku, serta sosialisasi sebelum diterapkan ke masyarakat.

3. Sangat penting untuk melaksanakan program pengembangan DME di daerah yang disesuaikan dengan potensi bahan baku yang dimiliki oleh daerah tersebut.

4. Perlu dilaksanakan inventarisasi potensi sumberdaya pada seluruh daerah yang dapat dimanfaatkan sebagai bahan baku DME, seperti limbah pertanian, kehutanan, industri, termasuk limbah perkotaan.

\section{KEPUSTAKAAN}

1. PTPSE, Outlook Energi Indonesia 2009, Pusat Teknologi Pengembangan Sumberdaya Energi - BPPT, 2010

2. Y. Ohno, N. Inoue, K. Okuyama, and T. Yajima, New Clean Fuel DME, DME Development Co. Ltd.,Japan, International Petroleum Technology Conference, 21-23 November 2005, Doha, Qatar

3. http://www.kilasberita.com/kb-finance/ ekonomi-a-moneter/5260-produksirendah-indonesia-resmi-keluar-dariopec

4. Myung Yoon Kim, et al, Combustion and Emission Characteristics of DME as an Alternative Fuel for Compression Ignition Engines with a High Pressure Injection System, Department of Mechanical Engineering, Hanyang University, Seoul, Korea, Volume 87, Issue 12, Fuel Processing Technology, September 2008, Pages 2779-2786..

5. Blue Print Pengelolaan Energi Nasional 2010 - 2025, ESDM, 2009

6. Nisandi, Pengolahan dan Pemanfaatan Sampah Organik Menjadi Briket Arang dan Asap Cair, Seminar Nasional Teknologi 2007 (SNT 2007) ISSN : 1978 - 9777, Yogyakarta, 24 November 2007

7. Studi Analisis dan Kajian Bidang Teknologi Energi, Korbid Energi-BPPT 2003

8. http://matainginbicara.wordpress. com/2008/06/03/dimetil-eterkandidat-"blue-energy"-yangsesungguhnya/

9. Shirish Bhide, at al, Characterization of the Viscosity of Blends of Dimethyl Ether with Various Fuels and Additives, The Energy Institute, The Pennsylvania State University

10. Troy A. Semelsberger, Rodney L. Borup, Howard L. Greene, Dimethyl Ether (DME) as an Alternative Fuel, 
Journal of Power Sources, Volume 156, Issue 2, June 2006, pp 497511

11. Y. Ohno, New Clean Fuel DME, JFE Holdings, Inc., Japan, DeWitt Global Methanol \& MTBE Conference, Bangkok, March 12-14 2007.
12. Sunggyu Lee, James G.Speight, Sudarshan K. Loyalka, Handbook of Alternative Fuels Technologies, CRC

Press, 2007, pp 119-120 